\title{
KONTROL OPTIMAL PADA MODEL PENYEBARAN VIRUS KOMPUTER DENGAN KLASIFIKASI PENGAMANAN
}

\author{
Pangestuti Prima Darajat ${ }^{1 \S}$, Tyas Husadaningsih ${ }^{2}$ \\ ${ }^{1}$ Universitas Islam Raden Rahmat Malang [Email: pangestuti_prima@uniramalang.ac.id] \\ ${ }^{2}$ Universitas Islam Raden Rahmat Malang [Email: tyas.husadaningsih@uniramalang.ac.id] \\ ${ }^{\S}$ Corresponding Author
}

\begin{abstract}
In this paper, a model of the spread of computer viruses with security classification and nonlinear infection rates is formulated. From the short analysis, is found that the model does not have a virusfree equilibrium point. This show that the virus will always exist in the system and increasingly that can not be avoided. Therefore, control strategy by installing antivirus on subpopulation susceptible low-security level and infective subpopulation aims to minimize the number of infective computers, and minimize the cost related to these strategies. Hence, an important tool, in this case is, optimal control theory. The system solved numerically by using Forward-Backward Sweep method in combination with the fourth-order Runge-Kutta method. Based on the simulation results, the combination of the two controls is effective in suppressing the spread of computer viruses. However, controlling by installing an antivirus on an infected computer has a great influence in suppressing the spread of the computer virus.
\end{abstract}

Keywords: Optimal Control, Mathematical Modeling, Computer Virus.

\section{PENDAHULUAN}

Tingginya ketergantungan berbagai bidang pada kinerja komputer menjadikan virus komputer sebagai ancaman yang serius. Tidak jarang kerusakan akibat virus ini dapat menyebabkan kerugian finansial yang besar. Sementara itu, software antivirus sebagai alat untuk mengatasi virus komputer memiliki kemampuan terbatas dan perkembangannya tertinggal oleh virus-virus berbahaya baru yang tercipta. Para peneliti telah mengembangkan berbagai model matematika untuk menggambarkan dinamika penyebaran virus komputer demi mendapatkan model yang sesuai dengan realita. (Yang, 2012-2014), (Zhu, 2013), (Gan, 2017), (Zhu, 2017), (Darajat, 2016).

Penelitian ini bertujuan untuk mengkontruksi model matematika yang lebih realistis tentang penyebaran virus komputer sekaligus mendapakan strategi yang efektif dalam penekan penyebaran virus komputer pada masa yang akan datang. Pada teori matematika terdapat dua pendekatan penting untuk mengontrol penyebaran virus, yaitu analisis kualitatif (analisis dinamik) dan teori kontrol optimal. Pada analisis dinamik kondisi penyebaran pada masa yang akan datang dapat diprediksi. Sementara itu, dengan teori kontrol optimal didefinisikan strategi-strategi untuk menekan penyebaran penyakit sehingga kemudian diperoleh strategi terbaik dalam menekan penyebaran penyakit (Darajat, 2016).

Pada penelitian ini dikonstruksi suatu model yang memodifikasi model penyebaran virus komputer dengan klasifikasi pengamanan oleh Zhu dan Cen pada tahun 2017 serta menggunakan laju infeksi nonlinear yang lebih realistis yang digunakan pada model Gan tahun 2017. Komputer bebas virus diklasifikasikan menjadi dua, yaitu Susceptible low security level $\left(S_{l}\right)$ sebagai subpopulasi komputer bebas virus yang memiliki pengamanan rendah dan Susceptible high security $\left(S_{h}\right)$ sebagai subpopulasi komputer bebas virus yang memiliki pengamanan tinggi. Sementara itu, subpopulasi komputer terinfeksi (Infected Computers) dinotasikan dengan I. Beberapa asumsi dikenakan pada model sedemikian sehingga dapat sesuai dengan kondisi sebenarnya yaitu, 
(i). Komputer $S_{l}$ dan $S_{h}$ terkoneksi dengan internet dengan laju sebesar $b_{l}$ dan $b_{h}$.

(ii). Masing-masing komputer akan terputus koneksinya dengan internet dengan laju sebesar $\mu$.

(iii). Didefinisikan parameter $\alpha$ sebagai laju komputer susceptible high security $\left(S_{h}\right)$ yang menjadi komputer susceptible low security $\left(S_{l}\right)$ karena melemahnya program antivirus pada komputer tersebut.

(iv). Akibat interaksi dengan komputer terinfeksi $I$, Komputer $S_{l}$ dan komputer $S_{h}$ akan terinfeksi dengan laju sebesar $\beta_{l} I$ dan $\beta_{h} I / f(I)$ dengan $f(I)=1+I$.

(v). Diasumsikan bahwa pengguna melakukan pembersihan menggunakan program antivirus pada komputer yang terinfeksi, dengan demikian komputer terinfeksi $I$ akan bersih dari virus dan berubah menjadi komputer $S_{l}$ dan $S_{h}$ dengan laju masing-masing sebesar $\gamma_{l} I$ dan $\gamma_{h} I$.

(vi). Akibat penggunaaan perangkat remofable storage, komputer $S_{l}$ akan terinfeksi dengan laju sebesar $\delta$.

Asumsi-asumsi yang telah dibangun di atas selanjutnya disajikan dalam diagram kompartmen pada Gambar 1.

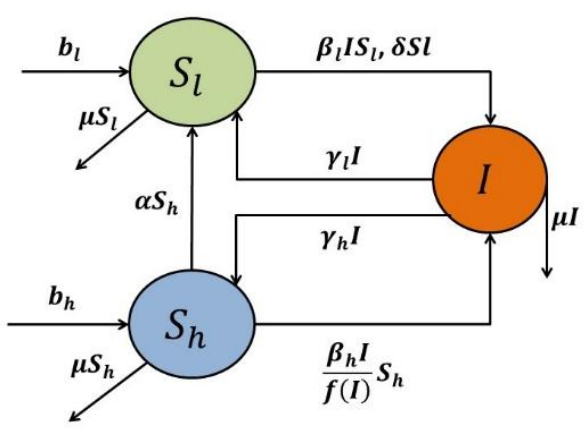

Gambar 1. Diagram Komartment Model

Model penyebaran virus komputer dengan klasifikasi pengamanan dan laju infeksi nonlinear adalah sebagai berikut,

$$
\begin{aligned}
& \dot{S}_{l}=b_{l}+\gamma_{l} I-\beta_{l} I S_{l}+\alpha S_{h}-\delta S_{l} \\
& -\mu S_{l} \\
& \dot{S}_{h}=b_{h}+\gamma_{h} I-\frac{\beta_{h} I}{1+I} S_{h}-\alpha S_{h}-\mu S_{h} \\
& \dot{I}=\beta_{l} I S_{l}+\frac{\beta_{h} I}{1+I} S_{h}-\gamma_{l} I-\gamma_{h} I+\delta S_{l} \\
& -\mu I
\end{aligned}
$$

Diketahui bahwa sistem persamaan (1) tidak memiliki titik kesetimbangan bebas virus. Hal ini dapat diinterpretasi bahwa, pada masa yang akan datang jumlah komputer terinfeksi semakin besar (Boyce, 2009). Simulasi sistem (1) dengan parameter merujuk pada Zhu tahun 2017 yang disajikan pada Tabel 1. adalah sebagai berikut,

Tabel 1. Nilai Parameter

\begin{tabular}{|c|c|}
\hline $\boldsymbol{b}_{\boldsymbol{l}}$ & 0,0012 \\
\hline $\boldsymbol{b}_{\boldsymbol{h}}$ & 0,0018 \\
\hline $\boldsymbol{\beta}_{\boldsymbol{l}}$ & 0,05 \\
\hline $\boldsymbol{\beta}_{\boldsymbol{h}}$ & 0,05 \\
\hline $\boldsymbol{\gamma}_{\boldsymbol{l}}$ & 0,146 \\
\hline $\boldsymbol{\gamma}_{\boldsymbol{h}}$ & 0,003 \\
\hline $\boldsymbol{\alpha}$ & 0,005 \\
\hline $\boldsymbol{\delta}$ & 0,003 \\
\hline $\boldsymbol{\mu}$ & 0,003 \\
\hline
\end{tabular}

Hasil Simulasi model dapat dilihat pada Gambar 2. Ditunjukkan bahwa jumlah komputer terinfeksi meningkat dari waktu-ke waktu. Sementara itu jumlah komputer $S_{l}$ maupun $S_{h}$ semakin menurun. Populasi awal $S_{l_{0}}=10$, $S_{h}=15, I=5$ untuk $T=25$ populasi akhir yang diperoleh adalah $S_{l_{0}}=3, S_{h}=4, I=20$.

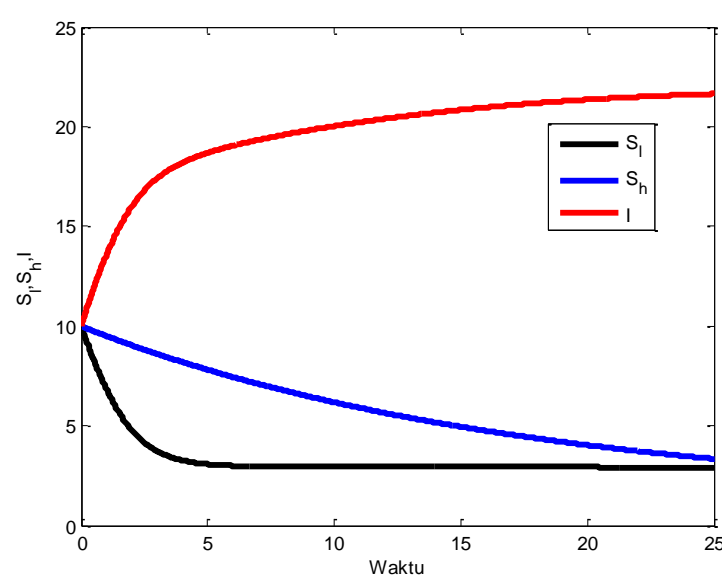

Gambar 2. Simulasi Model Penyebaran Virus Komputer dengan Klasifikasi Pengamanan

Oleh karenanya diusulkan beberapa strategi pengontrolan untuk menekan jumlah komputer terinfeksi. Strategi pengontrolan dengan menginstal antivirus pada komputer $S_{l}$ dinotasikan dengan $u_{1}(t)$. Pengontrolan ini ditujukan untuk menambah perlindungan komputer $S_{l}$ ketika berinteraksi dengan komputer terinfeksi maupun dengan perangkat removable storage. Strategi pengontrolan dengan menginstal antivirus pada komputer terinfeksi (I) dinotasikan dengan $u_{2}(t)$. Pengontrolan ini bertujuan untuk mengurangi jumlah penginfeksi. Dalam hal ini $u_{1}(t)$ dan $u_{2}(t)$ menyatakan nilai 
yang dinormalisasi sedemikian hingga batas kontrol diberikan sebagai berikut,

$$
\begin{gathered}
U_{a d}=\left\{u_{1}(t), u_{2}(t) \in L^{2}: 0 \leq u_{1}(t)\right. \\
\leq 1,0 \leq u_{2}(t) \leq 1, t \\
\in[0, T] .
\end{gathered}
$$

Berdasarkan keterbatasan kemampuan suatu antivirus, pada model kontrol diasumsikan bahwa, laju komputer terinfeksi $I$ yang menjadi komputer $S_{h}$ pada waktu $t$ adalah sebesar $\eta u_{2}(t)$ dan laju komputer terinfeksi yang menjadi komputer $S_{l}$ adalah sebesar (1$\eta) u_{2}(t)$ dengan $\in[0,1]$. Model penyebaran Virus komputer dengan penambahan kontrol adalah sebagai berkut,

$$
\begin{aligned}
& \dot{S}_{l}=b_{l}+\gamma_{l} I-\left(1-u_{1}\right)\left(\beta_{l} I S_{l}+\delta S_{l}\right) \\
& +\alpha S_{h}-\mu S_{l}+\eta u_{2} I \\
& \dot{S_{h}}=b_{h}+\gamma_{h} I-\frac{\beta_{h} I}{1+I} S_{h}-\alpha S_{h}-\mu S_{h} \\
& +(1-\eta) u_{2} I \\
& \dot{I}=\left(1-u_{1}\right)\left(\beta_{l} I S_{l}+\delta S_{l}\right)+\frac{\beta_{h} I}{1+I} S_{h} \\
& -\gamma_{l} I-\gamma_{h} I-\mu I-u_{2} I
\end{aligned}
$$

\section{METODE PENELITIAN}

Pada masalah kontrol optimal, variabel yang termuat pada sistem persamaan diferensial disebut sebagai variabel-variabel state. Variabelvariabel state ini akan dikendalikan dengan diberi perlakuan berupa fungsi kontrol yang sesuai. Fungsi kontrol yang dimaksud dapat mempengaruhi perilaku state sedemikian sehingga dapat mengoptimalkan fungsional objektif yang berbentuk integral fungsi yang bergantung pada variabel state dan variabel kontrol. Teknik utama untuk menyelesaikan masalah kontrol optimal adalah menentukan syarat perlu yang memenuhi kondisi optimal dan state. Syarat perlu yang diusulkan oleh Pontryagin pada tahun 1950 disebut sebagai fungsi adjoint. Fungsi adjoint digunakan untuk menambahkan persamaan diferensial pada fungsional objektif . Fungsi adjoint secara sederhana dapat dibangkitkan oleh fungsi Hamilton (Lenhart, 2015).

Kondisi optimal sistem ditentukan menggunakan prinsip Pontryagin dan selanjutnya diselesaikan secara numerik menggunakan metode Sweep Maju-Mundur dikombinasikan dengan metode Rungge-Kutta orde 4. Dibentuk fungsional objektif pada periode waktu $[0, T]$ yang mendeskripsikan tujuan pengontrolan yaitu meminimumkan jumlah komputer terinfeksi dan meminimumkan biaya total untuk menginstal antivirus pada komputer. Didefinisikan konstanta bobot seperti pada Tabel 2.

Tabel 2. Konstanta Bobot Fungsional Objektif.

\begin{tabular}{|c|l|}
\hline Notasi & \multicolumn{1}{|c|}{ Keterangan } \\
\hline$A_{1}$ & $\begin{array}{l}\text { konstanta bobot yang berkaitan } \\
\text { dengan jumlah komputer terinfeksi }\end{array}$ \\
\hline$A_{2}$ & $\begin{array}{l}\text { konstanta bobot yang berkaitan } \\
\text { dengan biaya pengontrolan } u_{1}(t) .\end{array}$ \\
\hline$A_{3}$ & $\begin{array}{l}\text { konstanta bobot yang berkaitan } \\
\text { dengan biaya pengontrolan } u_{2}(t) .\end{array}$ \\
\hline
\end{tabular}

Dengan demikian fungsional objektif yang akan diminimumkan adalah

$$
\begin{gathered}
\left.J\left(u_{1}, u_{2}\right)\right)=\int_{0}^{T}\left[A_{1} I(t)+A_{2} u_{1}^{2}(t)\right. \\
\left.+A_{3} u_{2}^{2}(t)\right] d t
\end{gathered}
$$

dengan kendala persamaan (2).

Variabel-variabel state pada masalah ini adalah $S_{l}(t), S_{h}(t)$, dan $I(t)$. Didefinisikan variabel-variabel adjoint yang bersesuaian untuk variabel-variabel state adalah $\sigma_{1}(t), \sigma_{2}(t)$, dan $\sigma_{3}(t)$. Selanjutnya, dapat dibentuk fungsi Hamilton sebagai berikut

$H\left(S_{l}, S_{h}, I, u_{1}, u_{2}, \sigma_{1}, \sigma_{2}, \sigma_{3}, t\right)=$

$A_{1} I(t)+A_{2} u_{1}^{2}(t)+A_{3} u_{2}^{2}(t)$

$+\sum_{i=1}^{3} \sigma_{i}(t) f_{i}\left(S_{l}, S_{h}, I, u_{1}, u_{2}\right)$,

dengan kondisi batas transversal adalah

$$
\sigma_{i}(T)=0, \quad i=1,2 .
$$

\section{HASIL DAN PEMBAHASAN}

\subsection{Penyelesaian Masalah Kontrol Optimal}

Penyelesaian masalah kontrol optimal akan disajkan pada teorema berikut,

Teorema 1. Pada masalah kontrol optimal persamaan (4) dengan kendala sistem persamaan (3), terdapat kontrol optimal $u_{1}^{*}(t)$, dan $u_{2}^{*}(t)$ dan solusi state optimal $S_{l}^{*}(t), S_{h}^{*}(t), I^{*}(t)$ sedemikian sehinggan nilai $J\left(u_{1}^{*}, u_{2}^{*}\right)$ minimum. Selain itu, terdapat variabel adjoint $\sigma_{1}, \sigma_{2}, \quad$ dan $\sigma_{3}$ yang memenuhi persamaan berikut, 


$$
\begin{aligned}
\frac{\partial \sigma_{1}}{\partial t}=-\sigma_{1}(-(1 & \left.\left.-u_{1}\right)\left(\beta_{l} I+\delta\right)-\mu\right) \\
& -\sigma_{3}\left(\left(1-u_{1}\right)\left(\beta_{l} I+\delta\right)\right) \\
\frac{\partial \sigma_{2}}{\partial t}=-\sigma_{1}(\alpha) & -\sigma_{2}\left(-\frac{\beta_{h} I}{1+I}-\alpha-\mu\right) \\
& -\sigma_{3}\left(\frac{\beta_{h} I}{1+I}\right) \\
\frac{\partial \sigma_{3}}{\partial t}=-A_{1}-\sigma_{1} & \left(\gamma_{l}-\left(1-u_{1}\right) \beta_{l} S_{l}\right. \\
& \left.+\eta u_{2}\right) \\
& -\sigma_{2}\left(\gamma_{h}-\frac{\beta_{h}}{(1+I)^{2}} S_{h}\right. \\
& \left.+(1-\eta) u_{2}\right) \\
& -\sigma_{3}\left(\left(1-u_{1}\right) \beta_{l} S_{l}\right. \\
& +\frac{\beta_{h}}{(1+I)^{2}} S_{h}-\gamma_{l}-\gamma_{h} \\
& \left.-\mu-u_{2}\right)
\end{aligned}
$$

dengan kondisi transversal pada persamaan (6).

Bukti. Sistem persamaan adjoint dan kondisi tranfersal ditentukan melalui fungsi Hamilton pada persamaan (4). Nilai negatif turunan fungsi Hamilton untuk masing-masing variabel state diperoleh yaitu memenuhi,

$$
\begin{aligned}
\frac{\partial \sigma_{1}}{\partial t}=-\frac{\partial H}{d S_{l}}= & -\sigma_{1}\left(-\left(1-u_{1}\right)\left(\beta_{l} I+\delta\right)\right. \\
& -\mu) \\
& -\sigma_{3}\left(\left(1-u_{1}\right)\left(\beta_{l} I+\delta\right)\right) \\
\frac{\partial \sigma_{2}}{\partial t}=-\frac{\partial H}{d S_{h}}= & -\sigma_{1}(\alpha) \\
& -\sigma_{2}\left(-\frac{\beta_{h} I}{1+I}-\alpha-\mu\right) \\
& -\sigma_{3}\left(\frac{\beta_{h} I}{1+I}\right) \\
\frac{\partial \sigma_{3}}{\partial t}=-\frac{\partial H}{d I}= & -A_{1}-\sigma_{1}\left(\gamma_{l}\right. \\
& \left.-\left(1-u_{1}\right) \beta_{l} S_{l}+\eta u_{2}\right) \\
& -\sigma_{2}\left(\gamma_{h}-\frac{\beta_{h}}{(1+I)^{2}} S_{h}\right. \\
& \left.+(1-\eta) u_{2}\right) \\
& -\sigma_{3}\left(\left(1-u_{1}\right) \beta_{l} S_{l}\right. \\
& +\frac{\beta_{h}}{(1+I)^{2}} S_{h}-\gamma_{l}-\gamma_{h} \\
& \left.-\mu-u_{2}\right)
\end{aligned}
$$

Kondisi optimal diperoleh ketika fungsi Hamilton memenuhi kondisi stasioner, yaitu

$$
0=\frac{\partial H}{\partial u_{k}^{*}}, \quad \forall u_{k}^{*}, k=1,2 .
$$

Berdasarkan kondisi stasioner pada persamaan (7), maka dapat ditentukan kondisi $u_{1}^{*}(t)$, $u_{2}^{*}(t)$, dan $u_{3}^{*}(t)$ agar diperoleh sistem optimal adalah sebagai berikut,

$$
\begin{gathered}
0=2 A_{2} u_{1}+\sigma_{1}\left(\beta_{l} I S_{l}+\delta S_{l}\right) \\
\quad-\sigma_{3}\left(\beta_{l} I S_{l}+\delta S_{l}\right) \\
0=2 A_{3} u_{2}+\sigma_{1} \eta I+\sigma_{2}(1-\eta) I-\sigma_{3} I
\end{gathered}
$$

Berdasarkan persamaan (9) dan (10), maka perhitungan nilai $u_{1}^{*}(t), u_{2}^{*}(t)$, dan $u_{3}^{*}(t)$ dapat dilakukan dengan persamaan sebagai berikut,

$$
\begin{aligned}
& u_{1}^{*}(t) \\
& =\min \left\{\max \left(0, \frac{\left(\sigma_{3}-\sigma_{1}\right)\left(\beta_{l} I S_{l}+\delta S_{l}\right)}{2 A_{2}}\right), 1\right. \\
& u_{2}^{*}(t) \\
& =\min \left\{\max \left(0, \frac{\left(\sigma_{3}-\sigma_{1} \eta-\sigma_{2}(1-\eta)\right) I}{2 A_{3}}\right),\right.
\end{aligned}
$$

Misalkan $S_{l}^{*}, S_{h}^{*}, I^{*}$ adalah kondisi state optimal, dan $\sigma_{1}^{*}, \sigma_{2}^{*}, \sigma_{3}^{*}$ adalah kondisi variabel adjoint yang bersesuaian. Kondisi optimal diperoleh dengan menyelesaikan sistem yang telah disubstitusikan nilai $u_{1}^{*}(t)$ dan $u_{2}^{*}(t)$ sebagai berikut

$$
\begin{aligned}
& \frac{d S_{l}^{*}}{d t}=f_{1}\left(S_{l}^{*}, S_{h}^{*}, I^{*}, u_{1}^{*}, u_{2}^{*}\right), \\
& \frac{d S_{h}^{*}}{d t}=f_{2}\left(S_{l}^{*}, S_{h}^{*}, I^{*}, u_{1}^{*}, u_{2}^{*}\right) \\
& \frac{d I^{*}}{d t}=f_{3}\left(S_{l}^{*}, S_{h}^{*}, I^{*}, u_{1}^{*}, u_{2}^{*}\right) \\
& \begin{aligned}
& \frac{\partial \sigma_{1}^{*}}{\partial t}=-\sigma_{1}\left(-\left(1-u_{1}\right)\left(\beta_{l} I+\delta\right)-\mu\right) \\
&-\sigma_{3}\left(( 1 - u _ { 1 } ) \left(\beta_{l} I\right.\right. \\
&+\delta)) \\
& \frac{\partial \sigma_{2}^{*}}{\partial t}=-\sigma_{1}(\alpha)-\sigma_{2}\left(-\frac{\beta_{h} I}{1+I}-\alpha-\mu\right) \\
&-\sigma_{3}\left(\frac{\beta_{h} I}{1+I}\right)
\end{aligned}
\end{aligned}
$$




$$
\begin{aligned}
\frac{\partial \sigma_{3}^{*}}{\partial t}=-A_{1}-\sigma_{1} & \left(\gamma_{l}-\left(1-u_{1}\right) \beta_{l} S_{l}\right. \\
& \left.+\eta u_{2}\right) \\
& -\sigma_{2}\left(\gamma_{h}-\frac{\beta_{h}}{(1+I)^{2}} S_{h}\right. \\
& \left.+(1-\eta) u_{2}\right) \\
& -\sigma_{3}\left(\left(1-u_{1}\right) \beta_{l} S_{l}\right. \\
& +\frac{\beta_{h}}{(1+I)^{2}} S_{h}-\gamma_{l}-\gamma_{h} \\
& \left.-\mu-u_{2}\right)
\end{aligned}
$$

\subsection{Simulasi Penyelesaian Secara Numerik}

Sistem persamaan optimal (12) akan diselesaikan secara numerik menggunakan metode sweep maju mundur yang dikombinasikan dengan metode Rungge-Kutta orde 4 (Lenhart, 2015). Parameter yang digunakan pada tabel 1 ditambahkan nila $\eta=0,6$. Simulasi dilakukan untuk membandingkan pengaruh pengontrolan $u_{1}, u_{2}$, dan keduanya terhadap sistem. .Nilai awal yang dihunakan adalah $\left(S_{l}, S_{h}, I\right)=(10,10,10)$.

Simulasi masing-masing upaya pengontrolan $u_{1}$ dan $u_{2}$ disajikan pada Gambar 3. Solusi numerik sistem tanpa kontrol (garis hitam) menunjukkan Jumlah komputer $S_{l}$ dan $S_{h}$ semakin berkurang sementara jumlah komputer terinfeksi $I$ semakin bertambah. Solusi sistem tanpa kontrol konvergen ke nilai $\left(S_{l}^{*}, S_{h}^{*}, I^{*}\right)=$ $(2.9,3.3,21.6)$. Pada saat diberikan strategi pengontrolan dengan menginstal antivirus pada komputer $S_{l}$ yaitu $u_{1}$ saja (Garis Merah) jumlah komputer $S_{l}$ meningkat secara signifikan akan tetapi jumlah komputer $S_{h}$ tetap turun seiring bertambahnya jumlah komputer terinfeksi (I). Hasil simulasi sistem dengan kontrol $u_{1}$ konvergen ke nilai $\left(S_{l}^{*}, S_{h}^{*}, I^{*}\right)=(22.0,3.4$, 2.5).

Ketika sistem diberikan strategi pengontrolan dengan menginstal antivirus pada komputer terinfeksi $I \quad\left(u_{2}\right)$ saja sistem konvergen ke titik $\left(S_{l}^{*}, S_{h}^{*}, I^{*}\right)=(12.5,13.1$, 2.3). Jumlah komputer $S_{l}$ dan $S_{h}$ bertambah meskipun kurang signifikan semetara komputer terinfeksi berkurang dengan cepat. Baik pengontrolan $u_{1}$ maupun $u_{2}$ dapat mengurangi jumlah komputer terinfeksi, namun jika digunakan pengontrolan $u_{1}$ saja kerusakan dan kerugian pada komputer $S_{h}$ tidak dapat dihindari. Sementara itu, jika digunakan pengontrolan $u_{2}$ saja jumlah komputer terinfeksi berkurang dengan lebih cepat sehingga kerugian dan kerusakan pada komputer $S_{h}$ maupun $S_{l}$ dapat dihindari.
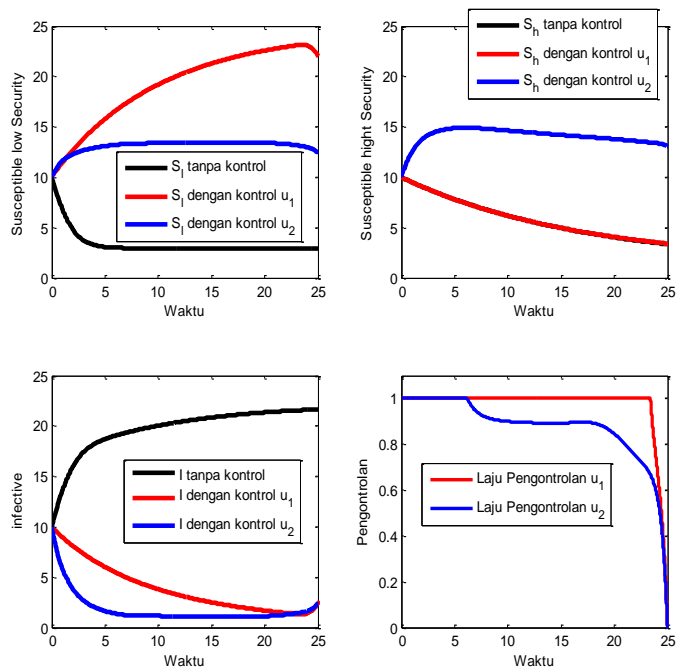

Gambar 3. Simulasi pengaruh masing-masing pengontrolan $u_{1}$ (Garis Merah) dan $u_{2}$ Garis Biru.

Simulasi selanjutnya digunakan kedua strategi kontrol yaitu $u_{1}$ dan $u_{2}$. Solusi numerik sistem (10) dengan kedua strategi kontrol konvergen ke titik $\left(S_{l}^{*}, S_{h}^{*}, I^{*}\right)=(17.6,10.3,0)$ seperti disajikan pada Gambar 4. Solusi sistem menggambarkan kedua pengontrolan dilakukan dengan maksimum $\left(u_{1}=u_{2}=1\right)$ sehingga jumlah komputer terinfeksi cepat menuju nilai 0 . Akibat dari kedua pengontrolan tersebut, jumlah komputer $S_{l}$ meningkat secara signifikan, sementara jumlah komputer $S_{h}$ cenderung tetap.
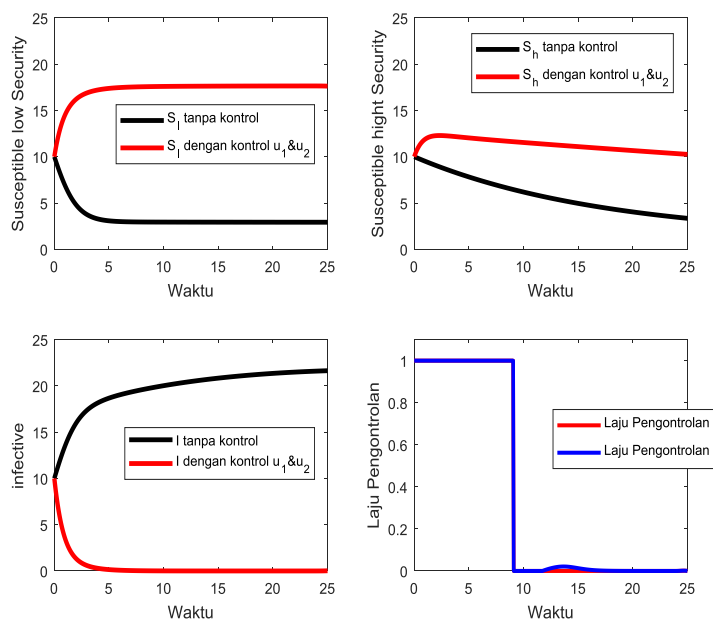

Gambar 4. Hasil simulasi pengaruh pengontrolan $u_{1}$ dan $u_{2}$ 
Berdasarkan hasil simulasi pada Gambar 3. Gambar 4. dapat diketahui bahwa pengontrolan dengan menginstal antivirus pada komputer $I$ saja lebih efektif dalam menekan penyebaran virus komputer dibandingkan pengontrolan dengan menginstal antivirus pada komputer $S_{l}$ saja. Dengan kata lain, menginstal antivirus pada komputer terinfeksi dapat meminimalisir subjek penginveksi secara langsung sehingga penyebaran virus komputer dapat diatasi. Namun demikian, kombinasi kedua pengontrolan yakni penginstalan antivirus pada komputer $S_{l}$ sebagai tindakan preventif pencegahan penyebaran virus komputer dan penginstalan antivirus pada komputer $I$ untuk mengurangi subjek penginveksi merupakan tindakan yang paling efektif untuk mengatasi penyebaran virus komputer.

\section{KESIMPULAN}

Berdasarkan hasil penelitian dapat disimpulkan bahwa, strategi pengontrolan penyebaran virus komputer yang efektif adalah dengan menginstal antivirus pada subpopulasi komputer dengan pengamanan lemah juga pada subpopulasi komputer terinfeksi. Pengontrolan pada subpopulasi komputer dengan pengamanan lemah bertujuan untuk melindung subpopulasi tersebut ketika berinteraksi dengan komputer terinfeksi maupun perangkat removable storage. Pengontrolan pada subpopulasi komputer terinfeksi bertujuan meminimalisir penginfeksi. Pengontrolan pada komputer terinveksi ini memiliki pengaruh yang signifikan dalam menekan penyebaran virus komputer.

\section{SARAN}

Pada penelitian selanjutnya dapat dikontruksi model penyebaran virus komputer lain yang lebih realistis dengan penambahan asumsi-asumsi lain. Strategi pengontrolan juga dapat diaplikasikan pada model penyebaran virus komputer lain karena telah terbukti efektif.

\section{DAFTAR PUSTAKA}

Boyce, W.E dan R.C. DiPrima. 2009. Elementary Differential Equations and Boundary Value Problems Eight Edition. USA: John Willey and Sons, Inc.

Chen, L., Hattaf, K., dan Sun, J. 2015. Optimal control of a Delayed SLBS computer virus model. Physica A. 427 : 244-250.
Darajat, P. P., Agus S., Agus W. 2016. Optimal Control On The Spread Of Slbs Computer Virus Model. International journal of pure and Applied Mathematics. 107:3.

Gan, C., Maobin Y., Zufan Z., dan Wanping L. 2017. Global Dynamics and Optimal Control of a Viral Infection Model with Generic Nonlinear Infection Rate. Discrete Dynamics in Nature and Society. 7571017.

Lenhart, S., dan Workman, J. T. 2015. Optimal Control Apllied to Biological Models. Taylor \& Francis Group. New York.

Yang, L. X., dan Yang, X. 2014. A New Epidemic Model of Computer Viruses. Commun Nonlinear Sci Numer Simulat. 19: 1935-1944.

Yang, L. X., Yang, X., Zhu, Q., dan Wen, L. 2013. A Computer Virus Model With Graded Cure Rates. Commun Nonlinear Sci Numer Simulat. 19: 1935-1944.

Yang, X., dan Yang, L. X. 2012. Towards the epidemiological Modeling of Computer Virus. Discrete Dynamics in Nature and Society. 25967.

Zhu, Q., dan Chen Cen. 2017. A Novel Computer Virus Propagation Model under Security Classification. Discrete Dynamics in Nature and Society. 8609082. 